Kılıç, S., \& Yılmaz, T. (2021). Yükseköğretimde ek ders ücret yönetim süreçlerinde yaşanan problemlerin tespiti ve bir bilişim sistemiyle çözüm önerisi. Aksaray Üniversitesi Sosyal Bilimler Enstitüsü Dergisi, 5(1), 61-84. doi:10.38122/ased.912673

\author{
Makale Geçmiși / Article History \\ Alindl (Received): 09/04/2021 \\ Düzeltme alındı (Received in revised form): 26/05/2021 \\ Kabul edildi (Accepted): 26/05/2021
}

\title{
Yükseköğretimde Ek Ders Ücret Yönetim Süreçlerinde Yaşanan Problemlerin Tespiti ve Bir Bilişim Sistemiyle Çözüm Önerisi
}

Selçuk KILIÇ', Tarık YILMAZ ${ }^{2}$

Özet: Bu çalışmanın ilk amacı öğretim elemanlarının ek ders yönetim süreçlerinde yaşadıkları problemleri tüm detaylarıyla tespit etmektir. İkinci amacı ise, tespit edilen problemlerin çözümüne yönelik yeni bir süreç tasarımını ve süreç içerisinde kullanılabilecek bir bilişim sisteminin işleyişi tanıtmaktır. Ek ders süreçleriyle ilgili öğretim elemanlarının karşılaştıkları problemlerin tespiti için alanyazında herhangi bir dayanak bulunmadığ 1 için karma yöntem bir araştırma tasarımı ve desen olarak da keşfedici sıralı desen uygulanmıştır. Öğretim elemanlarının ek ders süreçlerinde karşılaş̧ıkları olası problemler ve problemleri çözebileceğine inanılan bir bilişim sistemi önerisine yönelik düşünceleri üzerine nitel olarak veri toplanmıştır. Bu veriler, ortaya çıkma şartları, ortam, karşıllaşma sıklı̆̆ ve sonuçlar yönünden çözümlenmiştir. Bulunan sonuç kategorilerini birer biçim olarak kabul ederek nicel bir veri toplama aracı geliştirilmiş̧ir. Daha sonra bu araç daha fazla öğretim elemanı üzerinde bu biçimlerin ne kadar geçerli olduğunu değerlendirmek amaciyla kullanılmıştır. Elde edilen nitel ve nicel bulgular, gözlemler sonucunda elde edilen bulgularla desteklenerek mevcut durumda yaşanan problemler ve olası katılımcılardan gelen olası çözüm önerileri ortaya konulmuştur. Yaşanan problemlerin çözümüne yönelik bir bilişim sistemi geliştirilmesi önerisi yapılmış ve sistemin işleyişi hakkında bilgi verilmiştir.

Anahtar Kelimeler: Yükseköğretim, Ücret Yönetimi, Ek Ders, Bilişim Sistemi

\section{Determination of Problems of Additional Course Management Processes in Higher Education and Suggestion of Solutions with An Information System}

\begin{abstract}
The first aim of this study is to determine all the problems experienced by teaching staff in the course of additional course management process. The second aim is to introduce a new process design for the solution of the problems identified and the functioning of an information system that can be used in the process. As no basis was found in the literature for the identification of the problems faced by the teaching staff about the additional course processes, mixed method research paradigm has been utilized and the explanatory sequential design was applied as research design. Qualitative data were gathered on the opinions of the teaching staff about the possible problems they encountered in the additional course processes and their ideas about an information system proposal believed to be able to solve the problems. These data were analyzed in terms of the occurrence conditions, environment, frequency of encounter and results. A quantitative data collection tool has been developed by considering the result categories as a form. This tool was then used to evaluate the validity of these forms on more teaching staff. The problems experienced in the current situation and the possible solutions from the participants were presented by supporting the qualitative and quantitative findings with findings of the observations. It was proposed to develop an automation system for the solution of the problems and information was given about the process steps of the system.
\end{abstract}

Keywords: Higher Education, Wage Management, Additional Course, Information System

\footnotetext{
${ }^{1}$ selcukkilic@aksaray.edu.tr 0000-0002-9287-4754

2 tarikyilmaz@aksaray.edu.tr 0000-0003-1186-8780
} 


\section{Summary}

From the perspective of the instructor, it is very difficult to find a source in the literature that can answer the question of where to start in order to identify problems and current situations in the additional course wage process. In search engines, there are confusing presentations and documents that are copies of each other, where only the relevant laws, regulations, procedures and principles are given. It is thought that instructors faced difficulties in deciding which law or regulation to look at while calculating the course load and additional course fees. It is thought that by designing an informative and guiding system in additional course wage procedures, accounting officers and managers can be provided with great convenience. The main purpose of this study is to identify the problems faced by the instructors regarding the additional course wage processes, to analyze the current situation and to present possible solutions. There are many laws and articles that must be followed regarding the calculation and management of additional course fees. When evaluated from the perspective of the instructor, it is thought that a vast knowledge of legislation, ability, attention and time are needed to make all these complex calculations. In addition, since there may be days when the instructor is absent from the school by taking annual leave, excuse leave, hourly leave, health leave and cannot teach, the calculation process must be carried out every week during the education periods and in accordance with the relevant regulations. Taking advantage of an information system capable of executing all processes and calculations within the framework of laws and regulations in the most accurate way will both relieve the workload of teaching staff and increase the ability of managers to make decisions and manage information. Since there is no basis in the literature in order to identify the problems faced by the lecturers regarding the additional course processes and to analyze the current situation, it was decided to apply the mixed method and the exploratory sequential design as a research design. Mixed method research focuses on the collection, analysis and collation of both qualitative and quantitative data in a single study or a series of studies. In this study, qualitative data were collected on the possible problems faced by the instructors in the additional course wage processes and their thoughts on an information system proposal believed to be able to solve the problems. These data were analyzed in terms of emergence conditions, environment, frequency of encounter and results. A quantitative data collection tool was developed by accepting the results categories found as forms. Later, this tool was used to evaluate how valid these forms are on more instructors. The obtained qualitative and quantitative findings were supported by the findings obtained as a result of the observations, and the current problems and possible solution suggestions from possible participants were presented. As a result of the interviews with different instructors regarding the problems faced by the instructors in the additional course processes, it was understood that they mostly experienced problems during the preparation of the course load calculation form and the preparation of the payroll form. In accordance with the exploratory sequential design, a written questionnaire consisting of questions that may reveal prominent problems and other possible problems was developed in order to collect qualitative data in the first stage and was submitted to be filled in to a group of volunteer participants who were thought to be able to obtain accurate data by purposeful sampling method. The responses in the returned forms were coded with the content analysis method, and the prominent problems were identified in categories. Scale development for these categories was carried out in the second stage of the research. Based on the findings obtained in the first stage, a scale was developed for each question to be used in the second stage, which will constitute the quantitative data collection process of the research. The scale items are designed as Likert type and are 1- Strongly disagree, 2 Disagree, 3- Neither agree nor disagree, 4- Agree and 5- Strongly agree. The scales developed were tested on a small group of participants, and the understandability and reliability of the scales were tested. Later, the scales were transformed into an online questionnaire and the full population was targeted, and an invitation to participate in the survey was sent to all university instructors on a voluntary basis. The findings obtained from the participants who returned to the invitation positively were analyzed. In order to generalize the qualitative findings obtained in the first stage of the mixed method research, the categories revealed with the qualitative findings in the second stage were transformed into scale items and data were collected quantitatively. The quantitative findings and qualitative findings were generalized and it was observed that the quantitative findings coincided with the qualitative findings. Not contented with these findings, the problems experienced during the additional course management process and the general functioning were revealed with the observations made. In the light of the information obtained from the findings and observations, it was determined that various problems were experienced in the existing additional course management processes. It is thought that most of the problems identified are caused by the fact that the information cannot be managed properly and that in order to eliminate these problems, a user-friendly, stable information system with minimum error is needed. With the proposed model, the functioning of the information system designed to transform the additional course processes into a manageable form and how the workflow in the additional course processes will progress is described. With 
the designed information system, the additional course management process will be redefined, and it will be ensured that the whole process and calculations are carried out in the most accurate way within the framework of laws and regulations. It is thought that the information system, which will operate in the new process, can ease the workload of the teaching staff and increase the decision-making and knowledge management skills of the administrators. In this study, the problems experienced in the additional course management processes have been thoroughly examined and presented through the eyes of the instructor. A proposal was made to develop an information system to solve the problems encountered and information was given about the functioning of the system. In future studies, it can be examined whether there are different problems in different universities other than the problems identified in this study and new solutions can be developed for the problems identified. In addition, it can be examined as a different research subject whether the problems experienced with the implementation of the proposed information system are solved or not.

Keywords: Higher Education, Additional Course Management Processes, Information System

\section{GíRiş}

Ücret yönetimi insan kaynakları yönetiminin önemli konularından birisidir. Ücret, çalışanların ortaya koyduğu bedensel ve zihinsel emeğin bedeli olarak tanımlanabilir (Sabuncuoğlu, 1991). Çalışanlara ödenen kök ücret dışında genellikle performansa dayalı olarak uygulanan özendirici ücret modelleri de bulunmaktadır. Özendirici ücret modelleri, çalışanlara belirli bir işi yapma karşılı̆̆ı olarak ödenen kök ücretin dışında, işte gösterilen verimlilik, başarı ya da fazla hizmetin karşılı̆̆ 1 olarak işletmeler tarafından ikramiye, prim, ek ödeme, kar payı vb. şeklinde uygulanan ücret sistemleridir (Sabuncuoğlu, 2012). Özendirici ücret sistemlerin hedefi örgütün amacının gerçekleştirmesi için parasal özendirme yoluyla, baz ücret ve maaşların dışında ve üstünde ücret ödeyerek, işgörenin motivasyonunu olumlu yönde artırmaktır (Ergül, 2006). Çalışanların kazandıkları ücret ve yan haklar, onları motive etmede önemli bir role sahiptir. Bu durum özellikle çalışanların başarılarıyla bağlantılı olarak verilen ikramiyeler, ek ödemeler ve ödüller söz konusu olduğunda daha işlevseldir. Ücret ve sosyal hakların planlanması, genellikle karmaşık ve çok sayıda yasal bilgi gerektiren birçok kararı içermektedir (Noe, Hollenbeck, Gerhart ve Wright, 2018).

Özendirici bir ücret modeli olarak kabul edilen öğretim elemanlarına ödenen ek ders ücretlerinin hesaplanması birçok yasal bilgiyi gerektiren karmaşık bir sürece sahiptir. Süreç içerisinde ders yükünün tespit edilmesi ve ek ders ücretinin hesaplanması gibi konularda öğretim elemanları birinci derecede sorumluluğa sahiptir. Mevzuat bilgisi konusundaki yetersizlikler ya da yanlış anlaşılmalar öğretim elemanlarının ek ders ücreti konusunda problemler yaşamasına neden olabilmektedir.

Öğretim elemanı gözüyle ek ders süreçlerinde mevcut durumu ve yaşanan problemleri tespit etmek için nereden başlamak gerekir sorusuna yanıt verebilecek bir kaynağa alanyazında rastlamak güçtür. Arama motorlarında yapılan aramalarda yalnızca ilgili kanunlar, yönetmelikler, usul ve esaslara ilişkin bilgilerin verildiği kafa karıştırıcı sunular ve birbirinin kopyası olan belgeler bulunmaktadır. Öğretim elemanlarının ders yükü hesabı ve ek ders ücretlerini hesaplarken hangi kanuna veya yönetmeliğe bakacaklarına karar vermede güçlüklerle karşılaştığı düşünülmektedir. 
Yükseköğretim Kurulunun ve diğer birçok üniversitenin genel ağ sayfalarında "Ek ders ücretleri nasıl hesaplanır? Öğretim elemanları hesaplamada nelere dikkat etmelidir?” gibi kullanıcı dostu ve yönlendirici bilgiler yeterince yer almamaktadır. "Ders yükü tespiti ve ek ders ücreti ödemelerinde uyulacak esaslar” başlığı taşıyan ve Yükseköğretim Kurulu tarafından yayınlanan bir belge bile kurumun kendi sayfasında bulunmamaktadır. Ancak, farklı üniversitelerin genel ağ sayfalarından, memurlarla ilgili forumlardan ve T.C. Maliye Bakanlığı Bütçe Mali Kontrol Genel Müdürlüğü genel ağ sayfasından erişilebilmektedir (Google, 2018). Ek ders işlemlerinde bilgilendirici ve yol gösterici bir sistem tasarlayarak başta öğretim elemanlarına, muhasebe yetkililerine ve yöneticilere büyük kolaylıklar sağlanabileceği düşünülmektedir. Ek ders süreçleriyle ilgili öğretim elemanlarının karşılaştıkları problemlerin tespiti, mevcut durumun analiz edilmesi ve olası çözümlerin sunulması bu çalışmanın temel amacını oluşturmaktadır.

\section{EK DERS ÜCRET YÖNETIM SÜRECININ YASAL TEMELİ VE İŞLEYIŞİ}

Öğretim elemanları yükümlü oldukları asgari ders saati üzerinde verdikleri dersler için ek ders ücreti almaktadırlar. Bu durum 2547 sayılı kanunun 36’ncı maddesinde; “Öğretim üyesi, kadrosunun bulunduğu yükseköğretim birimi ile sınırlı olmaksızın ve ihtiyaç bulunması halinde görevli olduğu yükseköğretim kurumunda haftada asgari on saat ders vermekle yükümlüdür. Öğretim görevlisi ise haftada asgari on iki saat ders vermekle yükümlüdür.” ifadesiyle kanunlaştırılmıştır (2547 Sayılı Kanun, 1981).

Diğer taraftan, 2914 sayılı kanunun 11'inci maddesinin 1'inci fikrasında; “2547 Sayılı Yükseköğretim Kanununun 36'ncı maddesine göre haftalık okutulması mecburi ders yükü saati dışında, kısmi statüde bulunanlar dahil öğretim elemanlarına görev unvanlarına göre Maliye Bakanlığının görüşü üzerine Yükseköğretim Kurulu tarafından belirlenen mecburi ve isteğe bağglı dersler ve diğer faaliyetler için bu ders ve faaliyetlerin haftalık ders programında yer alması ve fiilen yapılması şartıyla en çok yirmi saate kadar, ikinci öğretimde ise en çok on saate kadar ek ders ücreti ödenir. Ders yüklerinin tamamlanmasında öncelikle normal örgün öğretimde verilen ders ve faaliyetler dikkate alınır." hükmüyle öğretim elemanının azami olarak alabileceği ders ücreti normal öğretim için azami 20, ikinci öğretim için azami 10 saat olarak sınırlandırılmıştır (2914 Sayılı Kanun, 1983).

Öğretim elemanlarının ek ders ücretlerinin hesaplanması ve ödeme işlemlerinin yönetimi konusunda yol gösterici olan ilgili kanunlar ve yönetmelikler şunlardır:

- 2547 sayıl1 kanunun 36. maddesi

- 2914 sayılı kanunun 11. maddesi ve ders yükü tespiti ve ek ders ücreti ödemelerinde uyulacak esaslar (Yükseköğretim Kurulu, 2005a) 
- 7100 sayılı kanunun ilgili maddeleri (7100 Sayılı Kanun, 2018)

- 2547 sayılı kanunun 44/e maddesi ve yükseköğretim kurumlarında uzaktan öğretime ilişkin usul ve esaslar (Yükseköğretim Kurulu, 2015)

- 2547 sayılı kanunun ek 26 maddesi ve yaz okulları programları uygulama esas ve usulleri (Yükseköğretim Kurulu, 2009)

- 2547 sayılı kanunun ek 27 maddesi ve tezsiz yüksek lisans programları uygulama esas ve usulleri (Yükseköğretim Kurulu, 2005b)

- 3843 sayılı kanunun 10. maddesi (3843 Sayılı Kanun, 1992) ve fazla çalışmayla ilgili 2013/5556 sayılı bakanlar kurulu kararı (Bakanlar Kurulu Kararı, 2013)

- 2547 sayılı kanunun 10. maddesi ve buna dayanılarak çıkarılan usul ve esaslar

Haftalık ders yükleri öğretim üyeleri ve öğretim görevlilerinin maaş karşılığı okutmuş olduğu dersler olarak nitelendirilebilir. Haftalık ders yükü öğretim üyeleri için 10, öğretim görevlileri için 12 saat olarak belirlenmiştir. Haftalık ders yükünü dolduran öğretim elemanlarının ücretini alabileceği azami ders saati Tablo 1'de gösterilmektedir.

Tablo 1. Ücret alınabilecek azami ders saati

\begin{tabular}{ccccc}
\hline Normal Öğretim & İkinci Öğretim & Uzaktan Öğretim & Tezsiz Y. Lisans Prog. & Toplam (Saat) \\
\hline 20 & 10 & 10 & 10 & 30 \\
\hline
\end{tabular}

Tablo 1'den anlaşılacağı üzere, öğretim üyesinin ek ders ücretini alabilmesi için öncelikle 10 saatlik maaş karşılığı derslerini yani haftalık ders yükünü tamamlaması gerekmektedir. Tamamladığ1 takdirde birinci öğretimde 20 saate kadar, ikinci öğretimde 10 saate kadar ve uzaktan öğretimde 10 saate kadar ek ders ücreti alabilecektir. Eğer tezsiz yüksek lisans programında da ders veriyorsa ve bu program ikinci öğretimde yürütülüyorsa öncelikli olarak kendi bölümünde girdiği ikinci öğretim ücretini aldıktan sonra 10 saatlik azami ikinci öğretim ücretinden geriye kalan ders saatinin ücretini alabilmektedir.

2547 sayılı kanunun 36'ncı maddesinin 5'inci fikrası uyarınca; rektör, dekan, enstitü ve yüksekokul müdürlerinin ders verme yükümlülükleri yoktur ve dolayısıyla haftalık ders yükleri “0”" olarak kabul edilir. Bu bağlamda, yukarıda adı geçen unvanlara sahip akademisyenler 1 saat ders yapsa bile haftalık ders yükü aranmaksızın ek ders ücreti alabilirler. Bununla birlikte rektör, dekan, enstitü ve yüksekokul müdür yardımcılarının ve bölüm başkanlarının ise haftalık ders yükleri tabloda yer alan verilerin yarısı olarak kabul edilir. Örneğin; idari bir görevi olmayan bir doktor öğretim üyesi haftalık ders yükü 10 saat iken bölüm başkanı olan doktor öğretim üyesinin haftalık ders yükü 5 saattir.

2914 sayılı kanunun 11'inci maddesinin 2'nci fikrasında ise “Mecburi ders yükünün tamamlanmasında ve ek ders ücretinin hesabında, teorik dersler dışındaki faaliyetlerin haftalık en 
fazla on saatlik kısmı dikkate alınır, kalan kısmı ise maaş karşılığı sayılır." hükmüyle uygulama derslerinin en fazla 10 saatine ücret verilebileceği belirtilmektedir.

Normal öğretim, ikinci öğretim ve uzaktan öğretimde ders veren bir öğretim elemanının ders ücreti örneğinin gösterildiği Şekil 1 incelendiğinde, hem zorunlu ders yükünün hesaplanmasında normal ve ikinci öğretimde verilen derslerin esas alınması, hem de uygulama saati kısıtına dikkat edilmesi gerekmektedir. Bu hesaba göre öğretim elemanı 3 saat ikinci öğretim ders ücretini ve 4 saat uzaktan öğretim uygulamalı ders ücretini alamamaktadır. Bu örnek dışında kafa karışıklığı yaratmamak için tezsiz ikinci öğretim yüksek lisans programı gösterilmemiştir. Eğer öğretim elemanı tezsiz bir programda ders vermiş olsaydı onun da ücretini alamayacaktı. Çünkü uygulama saati kısıtına takılıp yalnızca 9 saat ikinci öğretim ücreti alabilecekti.

Teorik

Uygulama

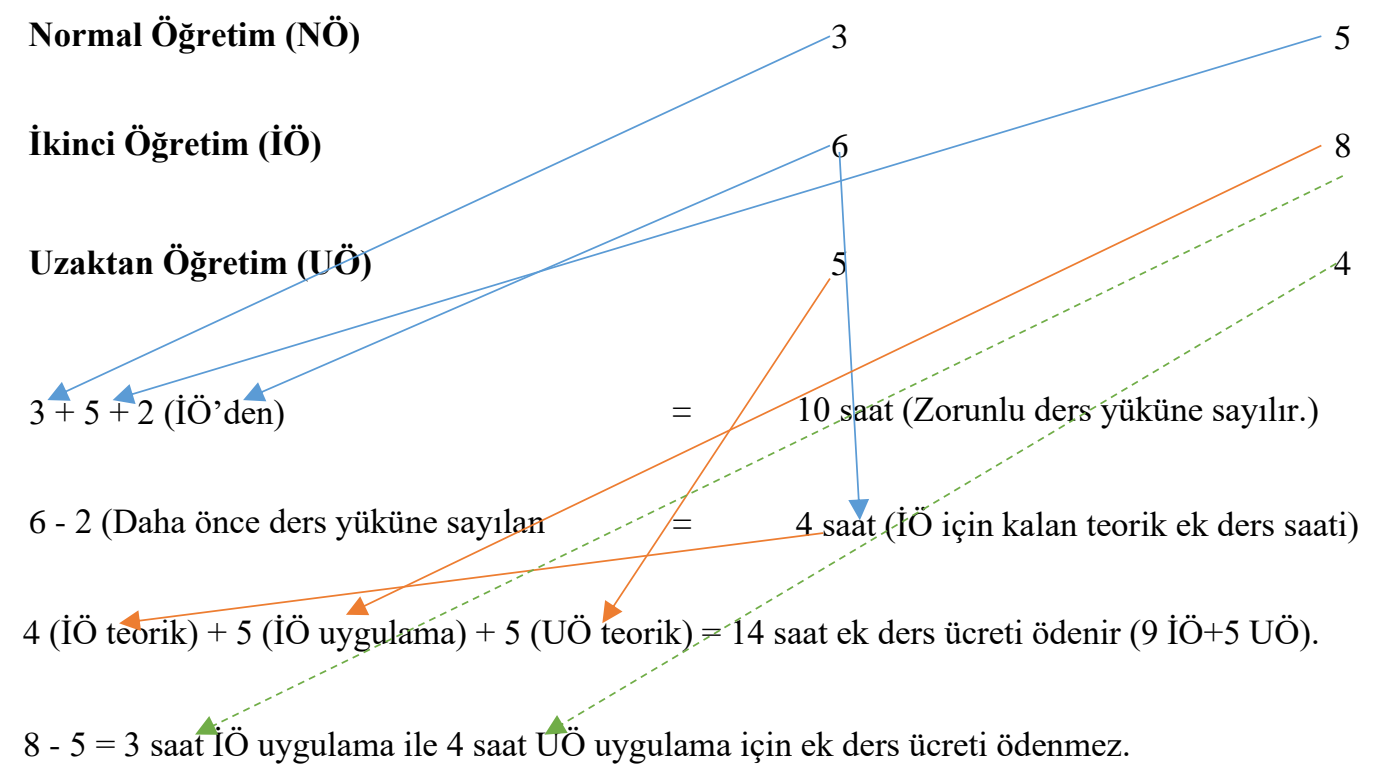

Şekil 1. Haftalık ders yükü hesaplama örneği

Öğretim elemanı gözüyle değerlendirildiğinde bütün bu karmaşık hesapların yapılabilmesi için engin bir mevzuat bilgisine, yeteneğe, dikkate ve zamana ihtiyaç bulunduğu düşünülmektedir. Ayrıca, öğretim elemanının yıllık izin, mazeret izni, saatlik izin, sağlık izni vb. alarak okulda bulunmadığı ve ders yapamadığı günler olabileceğinden hesaplama süreci, eğitim öğretim dönemleri boyunca ilgili yönetmelikler uyarınca her hafta yapılmalıdır. Bütün süreç ve hesaplamaları kanun ve yönetmelikler çerçevesinde en doğru şekilde yürütebilecek yeteneğe sahip bir bilişim sisteminden yararlanmak hem öğretim elemanlarının iş yükünü rahatlatacak, hem de yöneticilerin karar verme ve bilgiyi yönetebilme yeteneklerini artırabilecektir. 


\section{YÖNTEM}

Ek ders süreçleriyle ilgili öğretim elemanlarının karşılaştıkları problemlerin tespiti ve mevcut durumun analiz edilebilmesi için alanyazında herhangi bir dayanak bulunmadığı için karma yöntem bir araştırma tasarımı ve desen olarak da keşfedici sıralı desenin uygulanmasına karar verilmiştir. Karma yöntem araştırması tek bir araştırmada ya da bir araştırmalar dizisinde hem nitel hem de nicel verilerin toplanmasına, analiz edilmesine ve harmanlanmasına odaklanmaktadır. Temel önceliği nitel ve nicel verilerin birlikte kullanımı olup araştırma probleminin tek başına kullanılan herhangi bir yöntemden çok daha iyi bir şekilde anlaşılmasını sağlamaktır (Cameron, 2009; Creswell ve Plano Clark, 2014, s. 6; Ivankova, Creswell ve Stick, 2006).

Keşfedici sıralı desende sıralı bir zamanlama kullanılmaktadır. Keşfedici desen nitel verilerin toplanması ve analizine öncelik vermekte ve bunlarla başlamaktadır. Keşfedilen sonuçlar üzerinden araştırmacı ikinci aşamayı yani nicel aşamayı uygulamaya başlamakta ve birincil sonuçları test etmekte ve genelleştirmektedir. Daha sonra nicel verileri birincil nitel verilerin üzerine nasıl inşa ettiğini açıklamaktadır (Creswell ve Plano Clark, 2014). Nitel araştırmalarda genellikle tek bir veri kaynağına güvenmekten çok, mülakatlar, gözlemler ve dokümanlar gibi çoklu biçimlerde veri toplanabilmektedir. Daha sonra tüm veriler, veri kaynaklarının tamamına karşılık gelen kategoriler veya temalar halinde düzenlenerek, gözden geçirilmekte ve anlamlandırılmaya çalışılmaktadır (Creswell, 2013, s. 45). Araştırmadan elde edilecek bulguların genişletilmesi ve desteklenmesi için bu araştırmada ayrıca gözlemlerden de yararlanılmıştır.

$\mathrm{Bu}$ araştırmada öğretim elemanlarının ek ders süreçlerinde karşılaştıkları olası problemler ve problemleri çözebileceğine inanılan bir bilişim sistemi önerisine yönelik düşünceleri üzerine nitel olarak veri toplanmıştır. Bu veriler, ortaya çıkma şartları, ortam, karşılaşma sıklığı ve sonuçlar yönünden çözümlenmiştir. Bulunan sonuç kategorilerini birer biçim olarak kabul ederek nicel bir veri toplama aracı geliştirilmiştir. Daha sonra bu araç daha fazla öğretim elemanı üzerinde bu biçimlerin ne kadar geçerli olduğunu değerlendirmek amacıyla kullanılmıştır. Elde edilen nitel ve nicel bulgular, gözlemler sonucunda elde edilen bulgularla desteklenerek mevcut durumda yaşanan problemler ve olası katılımcılardan gelen olası çözüm önerileri ortaya konulmuştur.

\subsection{Birinci Aşama: Nitel Veri Toplama ve Analiz}

Ek ders süreçlerinde öğretim elemanlarının yaşadıkları sorunlara ilişkin olarak farklı öğretim elemanlarıyla görüşmeler sonucunda en çok ders yükü hesaplama formunun hazırlanması ve puantaj formunun hazırlanması aşamasında problemler yaşadıkları anlaşılmıştır. Keşfedici sıralı desene uygun olacak şekilde birinci aşamada nitel veri toplayabilmek için öne çıkan problemleri ve olası diğer problemleri ortaya çıkarabilecek sorulardan oluşan yazılı bir soru formu geliştirilmiş ve amaçsal 
örnekleme yöntemiyle doğru verilerin alınabileceği düşünülen gönüllü katılımcılardan oluşan bir gruba doldurulmak üzere teslim edilmiştir. Soru formunda yanıtlanması istenen sorular şunlardır:

Soru 1. Üniversitenizde ek ders ödeme işlemleri ve süreçlerine ilişkin yaşadı̆̆ınız genel problemler nelerdir?

Soru 2. Her eğitim ögretim dönemi başında sizlerden istenen "Ders Yükü ve Ek Ders Puantaj Hesaplama Tablosu Hazırlama” konusunda yaşadığınız problemler nelerdir?

Soru 3. Ĕ̆er üniversitenizde ek ders ile ilgili işlemler, bir bilgi yönetim sistemi yardımıyla yapılmış olsaydı ve siz çok az kullanıcı müdahalesiyle işlerinizi hatasız ve kolay bir şekilde gerçekleştirebilseydiniz ne düşünürdünüz? Sizce, böyle bir ek ders yönetim sisteminde olması gereken özellikler nelerdir?

Geri dönen formlarda yer alan yanıtlar içerik analizi yöntemiyle kodlanarak öne çıkan sorunlar kategoriler halinde belirlenmiştir. Bu kategorilere ilişkin ölçek geliştirme işlemi araştırmanın ikinci aşamasında gerçekleştirilmiştir. Neuendorf (2002, s. 1)'e göre içerik analizi, kısaca, mesaj özelliklerinin sistematik, objektif, niceliksel analizi olarak tanımlanmaktadır. Yıldırım ve Şimşek (2006, s. 227), benzer bir ifadeyle içerik analizini veriler tanımlanması ve verilerin içinde saklı olabilecek gerçekler ortaya çıkarılması olarak açıklamaktadırlar.

\section{2. İkinci Aşama: Nicel Veri Toplama, Katılımcı Grubu ve Analiz}

Birinci aşamada elde edilen bulgulardan yola çıkarak araştırmanın nicel veri toplama sürecini teşkil edecek ikinci aşamada kullanılmak üzere her soru için bir ölçek geliştirilmiştir. Ölçek maddeleri Likert tipi olarak tasarlanmış olup 1- Kesinlikle katılmıyorum, 2 Katılmıyorum, 3- Ne katılıyorum ne katılmıyorum, 4- Katılıyorum ve 5- Kesinlikle katılıyorum şeklindedir. Geliştirilen ölçekler küçük bir katılımcı grup üzerinde test edilmiş ve ölçeklerin anlaşılabilirliği ve güvenirliği sınanmıştır. Daha sonra ölçekler, çevrimiçi bir anket formuna dönüştürülerek ve tam sayım hedeflenerek ders ücreti alan üniversite öğretim elemanlarının tümüne gönüllük esasına göre ankete katılım konusunda davetiye gönderilmiştir. Davetiyeye olumlu olarak dönen katılımcılardan elde edilen bulgular analiz edilmiştir. Katılımcılara ilişkin bazı demografik bilgiler Tablo 2’de özetlenmiştir. 
Tablo 2. Katılımcılara İlișkin Demografik Bilgiler

\begin{tabular}{|c|c|c|c|c|c|}
\hline Cinsiyet & $\mathbf{f}$ & $\%$ & Çalışma Süresi & f & $\%$ \\
\hline Kadın & 116 & 36.1 & $0-5$ y1l & 97 & 31.2 \\
\hline Erkek & 205 & 63.9 & 6-10 yıl & 103 & 33.1 \\
\hline Toplam & 321 & 100 & 10 y1l üzeri & 111 & 35.7 \\
\hline & & & Toplam & 311 & 100 \\
\hline Unvan & f & $\%$ & & & \\
\hline Prof. Dr. & 25 & 7.9 & Yaş Aralığ & f & $\%$ \\
\hline Doç. Dr. & 55 & 17.4 & $35^{\prime}$ ten az & 93 & 29.7 \\
\hline Dr. Öğr. Üyesi & 120 & 37.9 & $35-40$ yaş & 112 & 35.8 \\
\hline Öğr. Gör. & 117 & 36.9 & 40 yaş üzeri & 108 & 34.5 \\
\hline Toplam & 317 & 100 & Toplam & 313 & 100 \\
\hline
\end{tabular}

Katılımcıların yaşları 26 ile 73 arasında değişmekte olup, ortalaması 39.19'dur. Çalışma süreleri 1 ile 57 yıl arasında değişmekte olup, ortalama çalışma süresi 10.96 yıldır. Unvan dağılımlarına göre katılımcıların yaklaşık \%63'ü öğretim üyesi, \%37'si de öğretim görevlisi kadrosunda bulunmaktadır.

Geliştirilen ölçeklerden beklenen öncelikli amaç ek ders süreçlerindeki mevcut durumu, yaşanan problemleri ve öğretim elemanlarının mevcut süreçten duydukları memnuniyetin ortaya konulmasıdır. $\mathrm{Bu}$ nedenle ölçeklerin kullandığı herhangi bir ilişkisel analize yer verilmemiştir. Yalnızca frekanslar, ortalama puanlar ve standart sapma puanları gibi merkezi eğilim istatistiklerinden yararlanılmıştır. Gerekli durumda ortalamalar ve frekanslardan hareketle amaca dönük grafiklerle bulgular oluşturulmaya çalışılmıştır.

\section{BULGULAR: MEVCUT DURUM VE YAŞANAN PROBLEMLER}

Mevcut durumu, yaşanan problemleri ve çözüme dönük olası beklentileri ortaya koyabilmek için yapılan analizlerin sonuçları nitel ve nicel bulgular olarak iki başlık halinde aşağıda açıklanmaktadır.

\subsection{Nitel Verilerden Elde Edilen Bulgular}

\subsubsection{Araştırmanın Birinci Sorusuna Verilen Yanıtlarla İlgili Bulgular}

"Soru 1. Üniversitenizde ek ders ödeme işlemleri ve süreçlerine ilişkin yaşadığınız genel problemler nelerdir?" sorusuna verilen yanıtlar içerik analizi yöntemiyle incelenmiştir. 15 katılımcıdan geri dönen formlar içerik analizi yapılarak öne çıkan temalar belirlenmiş, bu temalara ilişkin kategoriler (alt temalar) oluşturulmuş, kategorilerin oluşturulmasında kullanılan kodlar çerçevesinde içerikler analiz edilmiştir. Tema, kategori ve kodların belirlenmesinde kullanılan örnek ifadeler ile her bir kategori için hesaplanan frekans ve yüzde değerleri Tablo 3'te özetlenmektedir.

Tablo 3. Ek ders süreçlerinde yaşanan genel problemlere ilişkin yapılan içerik analizi sonucu oluşturulan temalar, kodlar ve örnek ifadeler

\begin{tabular}{lllll}
\hline Tema & Kategori & Örnek Kod & Örnek İfadeler & f \% \\
\hline Ücret & $\begin{array}{l}\text { Ders ücreti miktarının } \\
\text { belirsizliği }\end{array}$ & Ücret miktarı & Ücret ne kadar yatacak bilmiyorum & 640 \\
\hline
\end{tabular}


Tablo 3. Ek ders süreçlerinde yaşanan genel problemlere ilişkin yapılan içerik analizi sonucu oluşturulan temalar, kodlar ve örnek ifadeler

\begin{tabular}{|c|c|c|c|c|}
\hline Tema & Kategori & Örnek Kod & Örnek İfadeler & f \% \\
\hline & $\begin{array}{l}\text { Farklı birimler için ücret } \\
\text { miktarı belirsizliği }\end{array}$ & Farklı birimler & $\begin{array}{l}\text { Ders verdiğim farklı okullardan hangisinin ücret } \\
\text { yatırdığını bilemiyorum }\end{array}$ & 533 \\
\hline & $\begin{array}{l}\text { Beklenen ile alınan ücret } \\
\text { arasında uyumsuzluk }\end{array}$ & Ücret farklı & Yatan ücret miktarı beklediğimden az oluyor & 320 \\
\hline $\begin{array}{l}\text { Ödeme } \\
\text { Takvimi }\end{array}$ & $\begin{array}{l}\text { Ücretlendirmede farklı } \\
\text { takvimler olması }\end{array}$ & $\begin{array}{l}\text { Ödeme } \\
\text { zamanları }\end{array}$ & $\begin{array}{l}\text { Ders ücretleri belirli bir zamanda yatarsa daha } \\
\text { uygun olabilir }\end{array}$ & 747 \\
\hline $\begin{array}{l}\text { Sistem } \\
\text { Standardi- } \\
\text { zasyonu }\end{array}$ & $\begin{array}{l}\text { Standart bir } \\
\text { süreç } \\
\text { olmaması }\end{array}$ & $\begin{array}{l}\text { İzinliyken ders } \\
\text { ücreti }\end{array}$ & $\begin{array}{l}\text { İzinliyken ders ücreti alınmaması lazım ancak bazı } \\
\text { arkadaşlara izinliyken ücret yatırıldığını duyuyoruz }\end{array}$ & 640 \\
\hline $\begin{array}{l}\text { Sistemi } \\
\text { Karmaşık } \\
\text { Görme }\end{array}$ & $\begin{array}{l}\text { Süreçlerin } \\
\text { karmaşıklığ } 1\end{array}$ & Zor & $\begin{array}{l}\text { Çok dersiniz varsa ders yükünüzü hesaplamak için } \\
\text { çok uğraş verilmesi gerekiyor }\end{array}$ & 640 \\
\hline
\end{tabular}

Analiz sonucunda Soru 1 için verilen yanıtlar 4 tema ve 6 kategori altında gruplandırılmıştır. Oluşturulan temalar ücret miktarı, ödeme takvimi, sistem standardizasyonu ve sistemi karmaşık görme olarak belirlenmiştir.

\subsubsection{Araştırmanın İkinci Sorusuna Verilen Yanıtlarla İlgili Bulgular}

"Soru 2: Her Eğitim Öğretim dönemi başında sizlerden istenen "Ders Yükü ve Ek Ders Puantaj Hesaplama Tablosu Hazırlama” konusunda yaşadığınız problemler nelerdir?” sorusuna verilen yanıtlar içerik analizi yöntemiyle incelenmiştir. Tema, kategori ve kodların belirlenmesinde kullanılan örnek ifadeler ile her bir kategori için hesaplanan frekans ve yüzde değerleri Tablo 4'te özetlenmektedir.

Tablo 4. Ders yükü ve ek ders puantaj hesaplama tablosu hazırlama konusunda yaşanan problemlere iliş̧kin yapılan içerik analizi sonucu oluşturulan temalar, kodlar ve örnek ifadeler

\begin{tabular}{|c|c|c|c|c|}
\hline Tema & Kategori & $\begin{array}{l}\text { Örnek } \\
\text { Kod }\end{array}$ & Örnek İfadeler & f \% \\
\hline \multirow{2}{*}{$\begin{array}{l}\text { Bilgi ve } \\
\text { Güven } \\
\text { Eksikliği }\end{array}$} & $\begin{array}{l}\text { Süreç konusunda bilgi } \\
\text { sahibi olmama }\end{array}$ & Yetenekli & $\begin{array}{l}\text { Kendimi ders yükü tablosu dolduracak kadar yetenekli } \\
\text { görmüyorum }\end{array}$ & 533 \\
\hline & Yanlış yapma kaygısı & Hata & Ne zaman kendim yapsam hep hata çıkıyor & 427 \\
\hline $\begin{array}{l}\text { Süreci } \\
\text { Zaman } \\
\text { Kaybı } \\
\text { Görme }\end{array}$ & $\begin{array}{l}\text { Zaman kayb1 } \\
\text { Bürokrasi algıs1 }\end{array}$ & $\begin{array}{l}\text { Zaman } \\
\text { Bürokrasi }\end{array}$ & $\begin{array}{l}\text { Her dönem başında ders yükü hesabı için çok zaman harcıyoruz } \\
\text { İmzalarla uğraşılmasa keşke, süreç uzuyor }\end{array}$ & $\begin{array}{l}747 \\
640\end{array}$ \\
\hline $\begin{array}{l}\text { Süreci } \\
\text { Karmaş̧1k } \\
\text { Görme }\end{array}$ & $\begin{array}{l}\text { Hesaplama ve } \\
\text { tablolaş̧ırma süreci } \\
\text { karmaşı }\end{array}$ & Karmaşa & $\begin{array}{l}\text { Maaş karşılığını kendi fakültemden dolduramayınca hangi } \\
\text { birimden ücret alacağım, hangi birimi maaş karşıllğına } \\
\text { yazacağım konusu tam bir karmaşa }\end{array}$ & 533 \\
\hline
\end{tabular}

Analizi sonucunda Soru 2 için verilen yanıtlar 3 tema ve 5 kategori altında gruplandırılmıştır.

Oluşturulan temalar bilgi ve güven eksikliği, süreci zaman kaybı görme ve süreci karmaşık görme olarak belirlenmiştir. 


\subsubsection{Araştırmanın Üçüncü Sorusuna Verilen Yanıtlarla İlgili Bulgular}

"Soru 3: Eğer üniversitenizde ek ders ile ilgili işlemler bir bilgi yönetim sistemi yardımıyla yapılmış olsaydı ve siz çok az kullanıcı müdahalesiyle işlerinizi hatasız ve kolay bir şekilde gerçekleştirebilseydiniz ne düşünürdünüz? Sizce böyle bir ek ders yönetim sisteminde olması gereken özellikler nelerdir?” sorusuna verilen yanıtlar içerik analizi yöntemiyle incelenmiştir. Tema, kategori ve kodların belirlenmesinde kullanılan örnek ifadeler ile her bir kategori için hesaplanan frekans ve yüzde değerleri Tablo 5’te özetlenmektedir.

Tablo 5. Ek ders süreçleri bir bilişim sistemiyle yönetilmiş olsaydı beklentileriniz ne olurdu sorusuna ilişkin yapılan içerik analizi sonucu olușturulan temalar, kodlar ve örnek ifadeler

\begin{tabular}{|c|c|c|c|c|}
\hline Tema & Kategori & Örnek Kod & Örnek İfadeler & f \% \\
\hline \multirow[t]{2}{*}{ Güvenilir } & $\begin{array}{l}\text { Güvenilir } \\
\text { hesaplama } \\
\text { yapma }\end{array}$ & Güvenilir & Sistemin güvenilir bir şekilde çalışmasından herkes mutlu olur & 427 \\
\hline & $\begin{array}{l}\text { Bilgi } \\
\text { güvenliği }\end{array}$ & Bilgi güvenliği & $\begin{array}{l}\text { Bütün süreç bilgisayarlar aracılığıyla yapılırsa kişisel bilgilerin } \\
\text { güvenliğini korumak da gerekir }\end{array}$ & 320 \\
\hline \multirow[t]{2}{*}{$\begin{array}{l}\text { Tasarruf } \\
\text { Sağlayan }\end{array}$} & $\begin{array}{l}\text { Zaman } \\
\text { tasarrufu }\end{array}$ & Zaman & Bir bilgi sistemi kullanılırsa zamandan tasarruf edebiliriz & 747 \\
\hline & $\begin{array}{l}\text { İş yükünü } \\
\text { hafifletme }\end{array}$ & Kurtulma & $\begin{array}{l}\text { Derse girdiğim farklı fakültelere ders yükü tablosu ve puantaj } \\
\text { teslim etmekten kurtulurum }\end{array}$ & 747 \\
\hline $\begin{array}{l}\text { Kullanicı } \\
\text { Dostu }\end{array}$ & $\begin{array}{l}\text { Kolay } \\
\text { kullanım }\end{array}$ & Kolay & $\begin{array}{l}\text { Bazı üniversitelerde ek dersler bilgi sistemiyle yıllardır } \\
\text { yapılıyor, bizde de kullanımı kolay bir sistem neden olmasın? }\end{array}$ & 747 \\
\hline \multirow[t]{2}{*}{ Bilgilendirici } & $\begin{array}{l}\text { Ücret } \\
\text { konusunda } \\
\text { bilgilendirme }\end{array}$ & Bilgilendirme & Nereden, ne kadar ücret alacağımı belirtmesini isterdim & 853 \\
\hline & Şeffaflık & Şeffaf & $\begin{array}{l}\text { Bilgi sisteminde bölüm başkanı ve dekan her ögretim üyesinin } \\
\text { aldığı izni görebilmelidir }\end{array}$ & 640 \\
\hline
\end{tabular}

Yapılan içerik analizi sonucunda Soru 3 için verilen yanıtlar 4 tema ve 7 kategori altında gruplandırılmıştır. Oluşturulan temalar güvenilir, tasarruf sağlayan, kullanıcı dostu ve bilgilendirici olarak belirlenmiştir.

\subsection{Nicel Verilerden Elde Edilen Bulgular}

Nitel verilerin analiziyle elde edilen kategoriler ölçek maddeleri haline getirilmiştir. Nitel veri toplama aşamasında katılımcılara sorulan üç soru için üç ölçek hazırlanmıştır. Bunlar ek ders süreçleriyle ilgili algılanan genel sorunlar ölçeği, ders yükü ve ek ders puantaj tablosu hesaplama ölçeği ve önerilen bir bilişim sistemine yönelik algı ölçeği olarak belirlenmiştir. Bu ölçekler dışında ayrıca 9 aralıklı bir memnuniyet ölçeği hazırlanarak katılımcıların mevcut ek ders süreçlerine ilişkin memnuniyetleri tespit edilmeye çalışılmıştır.

Her bir ölçek için geliştirilen maddeler, ölçeğe ilişkin güvenirlik katsayıları ve katılımcılardan elde edilen veriler tablolar halinde aşağıda sunulmaktadır. Her tabloda ölçekte yer alan maddelerin ortalama ve standart sapma puanları ile frekans değerleri sunulmaktadır. 
Tablo 6. Ek ders süreçleriyle ilgili algılanan genel sorunlar

\begin{tabular}{|c|c|c|c|c|c|c|c|c|c|c|}
\hline \multirow{2}{*}{$\begin{array}{l}\text { Maddeler } \\
\text { (Cronbach's Alpha: 0.87) }\end{array}$} & \multirow[b]{2}{*}{ Ort. S.S. } & \multicolumn{2}{|r|}{1} & \multicolumn{2}{|c|}{2} & 3 & \multicolumn{2}{|r|}{4} & \multicolumn{2}{|r|}{5} \\
\hline & & $\mathbf{f}$ & $\%$ & $\mathbf{f}$ & $\%$ & $\%$ & $\mathbf{f}$ & $\%$ & $\mathbf{f}$ & $\%$ \\
\hline $\begin{array}{l}\text { 1. Her ay hak etmiş olduğum ek ders ücretlerimi hangi } \\
\text { tarihlerde alacağımı bilmiyorum }\end{array}$ & 4.121 .13 & 17 & 5.2 & 16 & 4.9 & 4012.2 & 93 & 28.4 & 161 & 499.2 \\
\hline $\begin{array}{l}\text { 2. Ek ders ücreti ödeme zamanlarında toplam ne kadar ek ders } \\
\text { ücreti alacağımı bilmiyorum }\end{array}$ & 3.781 .29 & 31 & 9.5 & 29 & 8.9 & 4112.5 & 106 & 32.4 & 120 & 36.7 \\
\hline $\begin{array}{l}\text { 6. Akademik birimler arasında ek ders ücretlendirme } \\
\text { takvimlerinde farklılık olduğunu düşünüyorum }\end{array}$ & 3.721 .26 & 28 & 8.6 & 26 & 8.0 & 7121.7 & 85 & 26.0 & 117 & 35.8 \\
\hline $\begin{array}{l}\text { 3. Ek ders ücreti ödeme zamanlarında görev yaptığım her bir } \\
\text { birimden ne kadar ek ders ücreti alacağımı bilmiyorum }\end{array}$ & 3.701 .33 & 36 & 11.0 & 30 & 9.2 & 4814.7 & 96 & 29.4 & 117 & 35.8 \\
\hline $\begin{array}{l}\text { 7. Akademik birimlerin kendi arasında ek ders ücret } \\
\text { ödemelerine ilişkin standart bir sistem olmadığını düşünüyorum }\end{array}$ & 3.481 .33 & 38 & 11.6 & 33 & 10.1 & 9228.1 & 63 & 19.3 & 101 & 30.9 \\
\hline $\begin{array}{l}\text { 10. Ek ders ücretlendirme süreçlerinin çok karmaşık olduğunu } \\
\text { düşünüyorum }\end{array}$ & 3.381 .31 & 37 & 11.3 & 46 & 14.1 & 8325.4 & 78 & 23.9 & 83 & 25.4 \\
\hline $\begin{array}{l}\text { 5. Ek ders ücret ödemelerinde standart bir ödeme planı } \\
\text { olmadığını düşünüyorum }\end{array}$ & 3.331 .42 & 44 & 13.5 & 59 & 18.0 & 7121.7 & 51 & 15.6 & 102 & 31.2 \\
\hline $\begin{array}{l}\text { 11. Ek ders ücretlendirme süreçlerinin sağlıklı olmadığını } \\
\text { düşünüyorum }\end{array}$ & 3.291 .32 & 41 & 12.5 & 47 & 14.4 & 9529.1 & 64 & 19.6 & 80 & 24.5 \\
\hline $\begin{array}{l}\text { 4. Beklediğim ek ders ücretleri ile aldığım ders ücretleri } \\
\text { arasında uyumsuzluk olduğunu düşünüyorum }\end{array}$ & 2.541 .33 & 93 & 28.4 & 772 & 23.5 & 8726.6 & 28 & 8.6 & 42 & 12.8 \\
\hline $\begin{array}{l}\text { 8. Ek ders ücret ödemelerinde öğretim elemanlarına eksik } \\
\text { ödeme yapıldığını düşünüyorum }\end{array}$ & 2.301 .21 & 105 & 32.1 & 922 & 28.1 & 8124.8 & 24 & 7.3 & 25 & 7.6 \\
\hline $\begin{array}{l}\text { 9. Ek ders ücret ödemelerinde öğretim elemanlarına fazla } \\
\text { ödeme yapıldığını düşünüyorum }\end{array}$ & 2.101 .15 & 127 & 38.8 & 922 & 28.1 & 7623.2 & 12 & 3.7 & 20 & 6.1 \\
\hline
\end{tabular}

Tablo 6'da ek ders süreçleriyle ilgili algılanan genel sorunlar ortalama puanlara göre azalan sırada verilmektedir. Öne çıkan temel sorunun ek ders ücretlerinin hangi tarihlerde ödeneceğine ilişkin bilgi eksikliğinden kaynaklandığı göze çarpmaktadır. İkinci sıradaki temel sorun ücret miktarları konusunda yaşanan bilgi eksikliğinden kaynaklanmaktadır. Akademik birimlerin ücret ödeme takvimlerinin farklı olması ise üçüncü sıradaki sorunu oluşturmaktadır. Nitel verilerle elde edilen bulguların gösterildiği Tablo 3 ile nicel verilerin gösterildiği bu veriler karşılaştırıldığında nitel ve nicel bulgular arasında bir paralellik bulunduğu göze çarpmaktadır. 
Tablo 7. Ders yükü ve puantaj hesaplama tablosuyla ilgili tespit edilen sorunlar

\begin{tabular}{|c|c|c|c|c|c|c|c|c|c|c|}
\hline \multirow{2}{*}{$\begin{array}{l}\text { Maddeler } \\
\text { (Cronbach's Alpha: 0.89) }\end{array}$} & \multirow{2}{*}{ Ort. S.S. } & 1 & \multicolumn{2}{|r|}{2} & \multicolumn{2}{|r|}{3} & \multicolumn{2}{|r|}{4} & \multicolumn{2}{|r|}{5} \\
\hline & & $\%$ & $\mathbf{f}$ & $\%$ & $\mathbf{f}$ & $\%$ & $\mathbf{f}$ & $\%$ & $\mathbf{f}$ & $\%$ \\
\hline $\begin{array}{l}\text { 4. Ders yükü ve ek ders puantaj hesaplama tablosunu hazırlamak } \\
\text { benim için zaman kaybına neden olur }\end{array}$ & 3.831 .2223 & 7.0 & 30 & 9.2 & 47 & 14.4 & 107 & 732.7 & 120 & 036.7 \\
\hline $\begin{array}{l}\text { 7. Ders yükü ve ek ders puantaj hesaplama tablosunu hatasız bir } \\
\text { şekilde hazırlayabilen sayısı çok azdır }\end{array}$ & 3.571 .1317 & 5.2 & 41 & 12.5 & 81 & 24.8 & 113 & 334.6 & 75 & 22.9 \\
\hline $\begin{array}{l}\text { 6. Ders yükü ve ek ders puantaj hesaplama tablosu hazırlanırken } \\
\text { çok fazla bürokratik adım gerekmektedir }\end{array}$ & 3.351 .1724 & 7.3 & 53 & 16.2 & 99 & 30.3 & 88 & 26.9 & 63 & 19.3 \\
\hline $\begin{array}{l}\text { 3. Ders yükü ve ek ders puantaj hesaplama tablosunu hazırlamak } \\
\text { için yardım alırım }\end{array}$ & 3.301 .2838 & 11.6 & & & & & 113 & 334.6 & 60 & 18 \\
\hline $\begin{array}{l}\text { 1. Ders yükü ve ek ders puantaj hesaplama tablosunu hazırlamak } \\
\text { benim için zordur. }\end{array}$ & 3.261 .2631 & 9.5 & 70 & 21.4 & 74 & 22.6 & 86 & 26.3 & 66 & 20.2 \\
\hline $\begin{array}{l}\text { 5. Ders yükü ve ek ders puantaj hesaplama tablosunu hazırlama } \\
\text { süreci çok karmaşıktır }\end{array}$ & 3.261 .2834 & 10.4 & 61 & 18.7 & 89 & 27.2 & 72 & 22.0 & 71 & 21.7 \\
\hline $\begin{array}{l}\text { 2. Ders yükü ve ek ders puantaj hesaplama tablosunu hazırlama } \\
\text { konusunda yeterli bilgiye sahip değilim }\end{array}$ & 3.061 .2940 & 12.2 & & 26. & 72 & 22.0 & 71 & 21.7 & 57 & 17.4 \\
\hline
\end{tabular}

Tablo 7'de ders yükü ve puantaj hesaplama tablosuyla ilgili tespit edilen sorunlar ortalama puanlara göre azalan sırada verilmektedir. Öne çıkan temel sorunun ders yükü ve ek ders puantaj hesaplama tablosunu hazırlamanın öğretim elemanlarınca zaman kaybına neden olduğu ifadesi olduğu dikkat çekmektedir. Hatasız yapabilmenin olanaksızlığına olan inanç ve bürokratik adımların gereksizliği ise diğer önemli sorun kaynaklarını göstermektedir. En düşük ortalama puana sahip ders yükü ve ek ders puantaj hesaplama tablosunu hazırlama konusunda yeterli bilgiye sahip değilim maddesi ise 3.06 gibi çok da düşük bir ortalama puana sahip değildir. Nitel verilerle elde edilen bulguların gösterildiği Tablo 4 ile nicel verilerin gösterildiği bu veriler karşılaştırıldığında nitel ve nicel bulgular arasında bir benzerlik bulunduğu dikkat çekmektedir.

Tablo 8. Katılımcıların önerilen bir bilișim sistemine yönelik algıları

\begin{tabular}{|c|c|c|c|c|c|c|c|c|c|c|c|c|}
\hline \multirow{2}{*}{$\begin{array}{l}\text { Maddeler } \\
\text { (Cronbach's Alpha: 0.95) }\end{array}$} & \multirow[b]{2}{*}{ Ort. } & \multirow[b]{2}{*}{ S.S. } & \multicolumn{2}{|c|}{1} & \multicolumn{2}{|c|}{2} & \multicolumn{2}{|r|}{3} & \multicolumn{2}{|c|}{4} & \multicolumn{2}{|c|}{5} \\
\hline & & & f & $\%$ & $\mathbf{f}$ & $\%$ & $\mathbf{f}$ & $\%$ & $\mathbf{f}$ & $\%$ & $\mathbf{f}$ & $\%$ \\
\hline $\begin{array}{l}\text { 7. Bu sistemde hangi birimden yaklaşık ne kadar ücret } \\
\text { alabileceğimi kolaylıkla öğrenebileceğimi düşünüyorum }\end{array}$ & 4.22 & 0.83 & 3 & 0.9 & 9 & 2.8 & 39 & 11.9 & 137 & 41.9 & 139 & 42.5 \\
\hline 2. Bu sistemin bana zaman kazandıracağını düşünüyorum & 4.18 & 0.89 & 3 & 0.9 & 16 & 4.9 & 38 & 11.6 & 133 & 40.7 & 137 & 41.9 \\
\hline 5. Bu sistemin kullanıcı dostu olacağını düşünüyorum & 4.16 & 0.83 & 0 & 0.0 & 11 & 3.4 & 56 & 17.1 & 129 & 39.4 & 131 & 40.1 \\
\hline 4. Bu sistemin şeffaf olacağını düşünüyorum & 4.14 & 0.83 & 1 & 0.3 & 10 & 3.1 & 57 & 17.4 & 132 & 40.4 & 127 & 38.8 \\
\hline 6. Bu sistemin iş yükümü azaltacağını düşünüyorum & 4.13 & 0.94 & 3 & 0.9 & 18 & 5.5 & 52 & 15.9 & 113 & 34.6 & 141 & 43.1 \\
\hline $\begin{array}{l}\text { 1. Bu sistemin başarılı bir şekilde sürdürülebileceğini } \\
\text { düşünüyorum }\end{array}$ & 4.10 & 0.87 & 3 & 0.9 & 11 & 3.4 & 59 & 18.0 & 132 & 40.4 & 122 & 37.3 \\
\hline $\begin{array}{l}\text { 3. Bu sistemin kişisel bilgilerim açısından güvenilir } \\
\text { olacağını düşünüyorum }\end{array}$ & 4.01 & 0.93 & 3 & 0.9 & 18 & 5.5 & 68 & 20.8 & 122 & 37.3 & 116 & 35.5 \\
\hline
\end{tabular}

Tablo 8'de katılımcıların ek ders süreçlerini kolaylaştıracak önerilen bir bilişim sistemine yönelik algıları ortalama puanlara göre azalan sırada verilmektedir. Öne çıkan temel beklentinin önerilen sistemde hangi birimden yaklaşık ne kadar ücret alabileceğinin kolaylıkla öğrenebilmesine yönelik inanç olduğu görülmektedir. Önerilen bilişim sistemimin zaman tasarrufu sağlayacağı ve kullanıcı dostu olacağına olan inanç ise diğer önemli beklentiler olarak sıralanmaktadır. En düşük ortalama 
puana sahip önerilen bilişim sisteminin kişisel bilgiler açısından güvenilir olacağına olan inanç ise 4.01 gibi ortalamanın üstünde puana sahiptir. Nitel verilerle elde edilen bulguların gösterildiği Tablo 5 ile nicel verilerin gösterildiği bu veriler karşılaştırıldığında nitel ve nicel bulgular arasında bir benzerlik bulunduğu göze çarpmaktadır.

Katılımcıların mevcut ek ders ücretlendirme süreçlerine ilişkin memnuniyetlerini ölçebilmek için 1Hiç memnun değilim ile 9- Çok memnunum arasında değişen 9 aralıklı bir memnuniyet puan ölçeği kullanılmıştır. Verilen yanıtlar Şekil 2'de daha iyi anlaşılması için bir sütun grafikten yararlanarak gösterilmiştir.

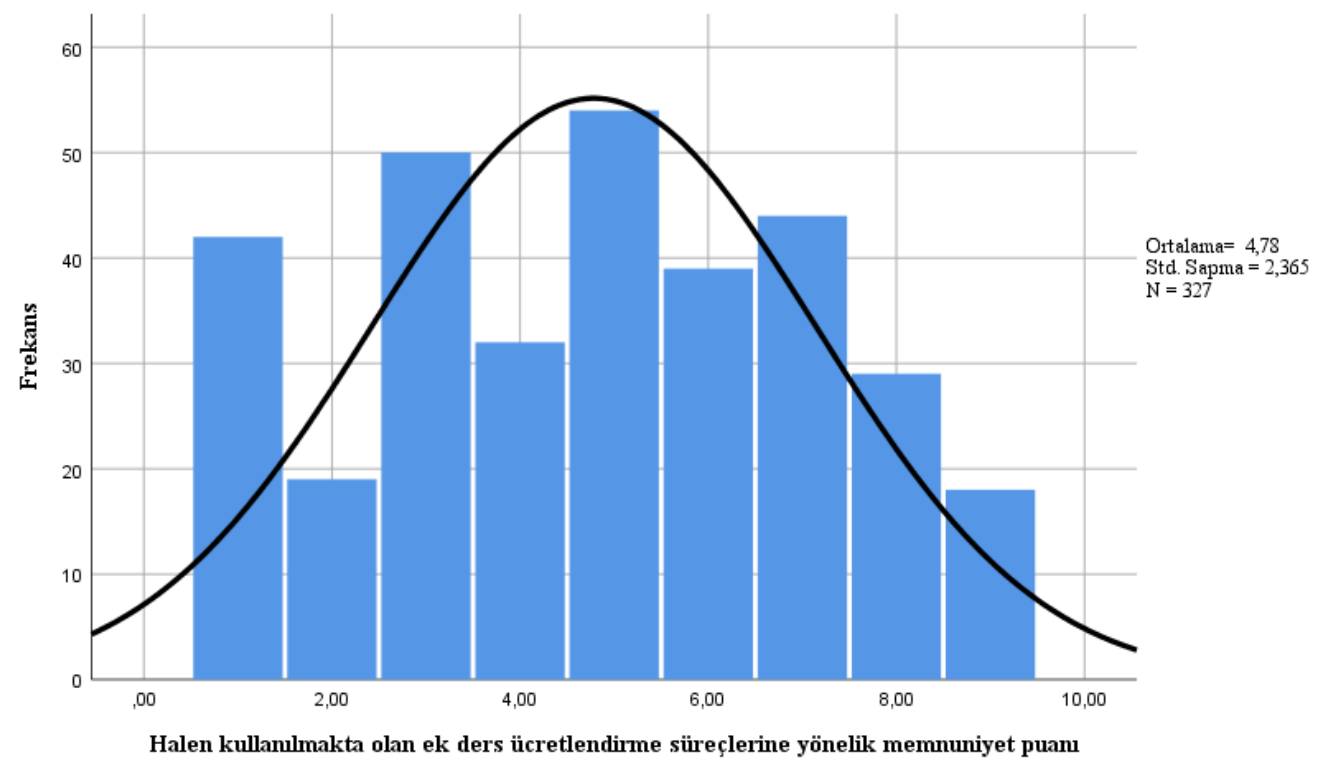

Şekil 2. Mevcut ek ders süreçlerine ilişkin memnuniyet

Katılımcıların mevcut ek ders ücretlendirme süreçlerine ilişkin memnuniyet puanları incelendiğinde ortalamanın altında (4.78) bir memnuniyete sahip oldukları anlaşılmaktadır. 1 en düşük - 9 en yüksek memnuniyet puanını gösterirken, 5 puan ortalama memnuniyet düzeyini işaret etmektedir. Memnuniyet düzeyinin ek ders ücretlendirme süreçlerinde yaşanan problemlerle bir ilişkisi olup olmadığını anlayabilmek için Şekil 3’te verilen çizgi grafik oluşturulmuştur. 


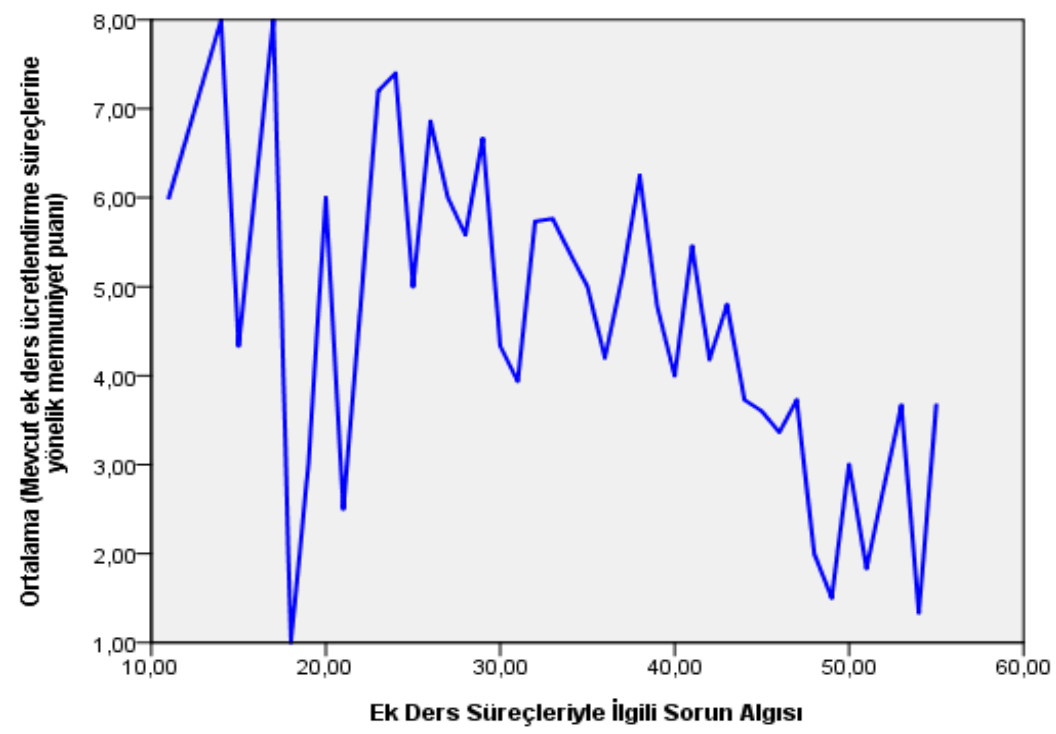

Şekil 3. Mevcut ek ders ücretlendirme süreçlerine yönelik memnuniyet ve sorun algısı arasındaki ilişki Şekil 3 incelendiğinde ek ders süreçleriyle ilgili yaşanan sorunlara yönelik algı arttıkça memnuniyet puanlarının azaldığı görülmektedir. 11 maddeden oluşan genel sorun algısı ölçeğinden alınabilecek en düşük puan 11, en yüksek puan ise 55'tir. Katılımcıların ölçekte yer alan ifadelere verdikleri yanıtların ortalaması 35.74 olarak hesaplanmıştır. Her bir memnuniyet puanına karşılık gelen sorun algısı ortalaması ile oluşturulan grafik, yaşanan memnuniyetsizliğin nedeninin ek ders ücretlendirme süreçlerinde yaşanan problemlerde aramak gerektiğini göstermektedir.

\subsection{Mevcut Durumda Ek Ders Yönetim Sürecine İlişkin Gözlemler}

Karma yöntem araştırmasının birinci aşamasında elde edilen nitel bulguları genelleştirebilmek için, ikinci aşamada nitel bulgularla ortaya çıkarılan kategoriler ölçek maddelerine dönüştürülmüş ve nicel olarak veri toplanmıştır. Nicel bulgular ile nitel bulguların genelleştirilmesi yapılmış ve nicel bulguların nitel bulgularla örtüştügü görülmüştür. Elde edilen bu bulgularla yetinmeyip yapılan gözlemlerle ek ders sürecinde yaşanan problemler ve genel işleyiş ortaya konulmuştur. Yaşanan problemlere bir çözüm niteliği olarak önerilen bilişim sistemi bir sonraki başlık altında incelenmektedir.

Nitel araştırmalarda katılımlı gözlem yöntemi önemli bir veri toplama aracı olarak kabul edilmektedir. $\mathrm{Bu}$ yöntemde araştırmacı veri toplarken topluluk içerisinde aktif olarak görev almaktadır. Katılımlı gözlem, gözlemci olarak katılım ve tam katılım olmak üzere iki boyutta gerçekleştirilebilmektedir (Baş ve Akturan, 2017, s. 102). Bir araştırmacı birçok nedenden dolayı gözlemden yararlanarak veri toplamak isteyebilir. Katılımcı gözlemci olayları bizzat görür, gözlemleneni yorumlarken ve görüşmeden çıkarılan bulguları değerlendirirken kendi bilgi ve uzmanlığını kullanır. Gözlem, davranışı olduğu gibi kaydetmeye olanak sağlamaktadır (Merriam, 2015, ss. 112-113). Gözlem, önüne gelen olguyu toplama işlemi değildir. Gözlem olgunun içinde 
geçtiği olayları, araştırılan probleme göre belli grup veya sınıf altında toplamaktır. Gözlemlenmiş bir olgu ne denli basit olursa olsun aslında yorumlanmış bir algı kümesidir (Büyüköztürk, Akgün, Karadeniz, Demirel ve Kılıç Çakmak, 2012, s. 8). Bir gözlemin bilimsel değeri güvenirlik ve geçerlik temel koşullarını yerine getirme gücüne bağlıdır. Güvenilir gözlem her şeyden önce nesnel nitelikte olan gözlemdir. Ancak yüzde yüz nesnellikten söz edilemez. Her gözlem, gözlemcinin amaç, ilgi ve yaşantısına sıkı sıkıya bağlıdır. Önemli olan gözlemcinin olgulara yaklaşımında kişisel saplantı, ön yargı veya inançların etkisinde kalmaması, bilerek ya da bilmeyerek olguları olduğundan başka türlü göstermemesidir (Büyüköztürk vd., 2012, s. 9).

Yapılan gözlemlerle ilgili elde edilen bulgular, yalnızca bir araştırmacının gözlemlerine değil, bu araştırmanın yürütülmesinde görev alan iki araştırmacının ve süreç içinde aktif olarak görev alan mutemetlerin gözlemlerine dayalı olarak ortaya konulmuştur. Elde edilen gözlem bulgularına göre, ek ders ödemelerinin gerçekleştirilmesinde öğretim elemanı, öğretim elemanının ders verdiği ilgili bölümün başkanı ve öğretim elemanının ders verdiği ilgili okul yöneticisi (dekan ya da müdür) etkin olarak görev almaktadır. Öğretim elemanı her dönem başlangıcında verdiği dersleri ve ders programını kontrol ederek, haftalık ders yükü hesabını yapmaktadır. Haftalık ders yüküne göre ders verdiği her ay için puantaj hesaplamaktadır. Eğer izinli olduğu günler varsa puantaj hesabında bu günleri çıkarmaktadır. Telafi yapmak istiyorsa okul yöneticiliğinden aldığı resmi onay doğrultusunda ilgili haftada dersinin telafisini yaparak puantajını güncellemektedir.
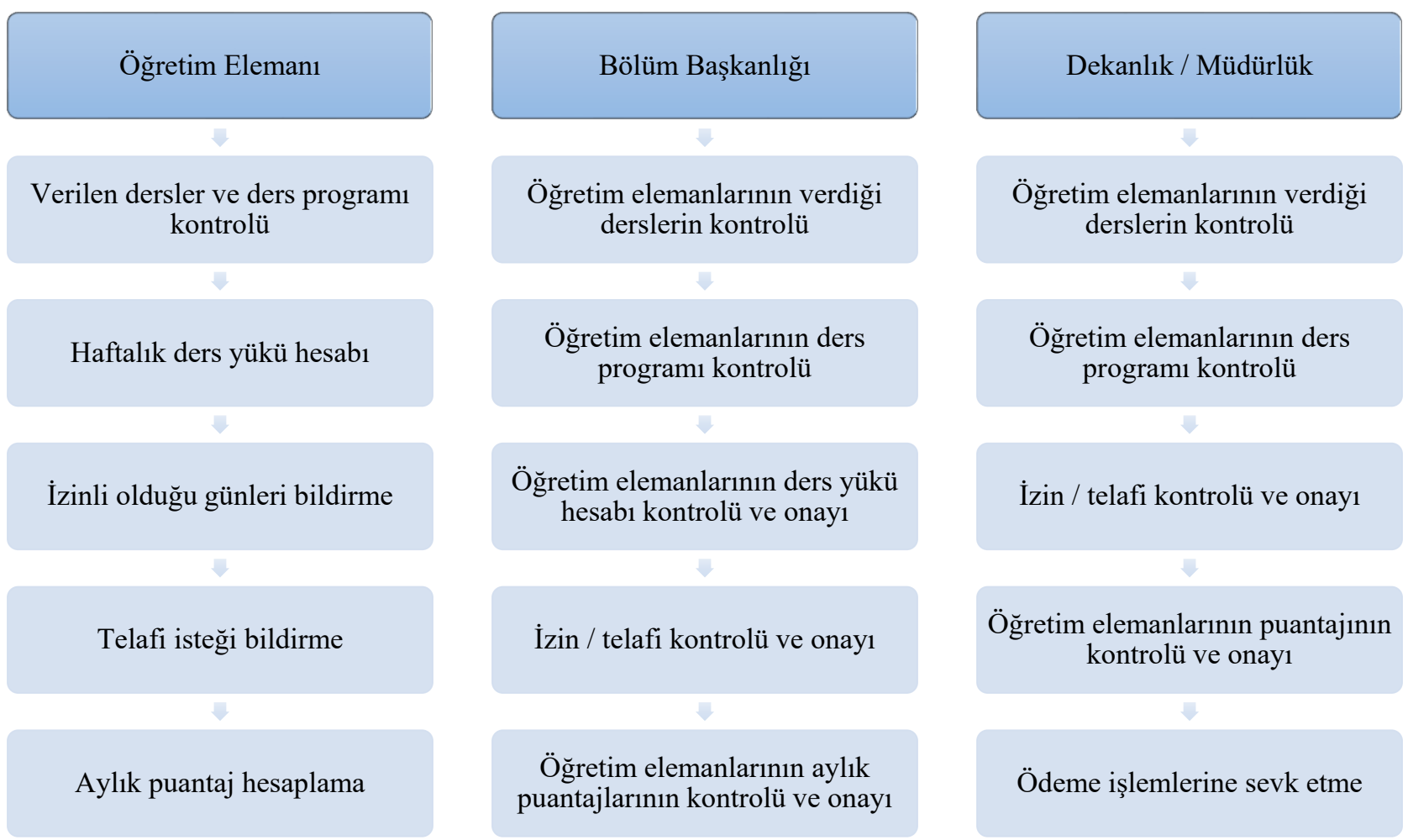


\section{Şekil 4. Ek ders ödeme işlemlerinin işleyişi}

Bölüm başkanı her dönem başlangıcında bölümde ders veren öğretim elemanlarının verdiği dersleri ve ders programını kontrol ederek, haftalık ders yükü hesabını kontrol etmektedir. Öğretim elemanlarının haftalık ders yüküne göre ders verdiği her ay için puantaj hesaplarını kontrol etmektedir. Eğer öğretim elemanının izinli olduğu günler varsa puantaj hesabında bu günleri çıkarılıp çıkarılmadığını kontrol etmektedir. Telafi isteği varsa okul yöneticiliğinden alınan resmi onay doğrultusunda ilgili haftada dersin telafisinin yapılıp yapılmadığını ve puantajın doğru olup olmadığını kontrol etmektedir.

Okul yöneticisi, mutemet ile birlikte her dönem başlangıcında her bölümde ders veren öğretim elemanlarının verdiği dersleri ve ders programlarını kontrol ederek, haftalık ders yükü hesaplarını kontrol etmektedir. Öğretim elemanlarının haftalık ders yüküne göre ders verdiği her ay için puantaj hesaplarını kontrol etmektedir. Eğer öğretim elemanının izinli olduğu günler varsa puantaj hesabında bu günleri çıkarılıp çıkarılmadığını kontrol etmektedir. Telafi isteği varsa okul yöneticiliğinden alınan resmi onay doğrultusunda ilgili haftada dersin telafisinin yapılıp yapılmadığını ve puantajın doğru olup olmadığını kontrol etmektedir. Hesaplamalarda bir sorun yoksa ödeme işlemlerine sevk etmektedir.

Elde edilen bulgular ve ek ders süreçlerinde yer alan mutemet ve yöneticilerden elde edilen bilgiler 1şı̆̆ında mevcut durumda ek ders ödeme işlemlerinde karşılaşılan sorunlar şu şekilde ifade edilebilir:

- Ders yükü hesabının nasıl yapılacağını bilmeme ya da yanlış yapma

- Ders yükü hesabını yaparken maaş karşılığı ve ders ücreti alması gereken birimleri belirleyememe

- Ders yükü hesabında teorik ve uygulamalı dersler için yanlış hesaplama yapma

- Resmi bir görev dolayısıyla ders veremediği günleri ders verdiği bütün birimlere bildirmeme

- İzinli olduğu günler için ders veremediği günleri ders verdiği bütün birimlere bildirmeme

- İzinli ya da görevli olduğu günler için ders telafisi onayı almadan okul yöneticiliğinin bilgisi dışında puantaj hesaplama

- İzinli ya da görevli olduğu günlerde almaması gereken ders ücretinin yanlışlıkla yatırılması ve Sayıştay tarafından bu durumun tespit edilerek öğretim elemanına uyarı verilmesi ve yatırılan ücretin faizi ile birlikte iade edilmesi

Yapılan gözlemler sonucunda elde edilen bulguların, elde edilen nitel ve nicel bulgularla örtüştüğü ifade edilebilir. 


\section{SONUÇLAR VE TARTIŞMALAR: ÖNERILEN MODEL VE ÇÖZÜMLER}

Elde edilen bulgulardan ve yapılan gözlemlerden elde edilen bilgiler ışığında mevcut ek ders yönetim süreçlerinde tespit edilen problemlerin birçoğunun bilginin doğru bir şekilde yönetilemediğinden kaynaklandığı ve bu problemlerin ortadan kaldırılması için kullanıcı dostu, istikrarlı ve minimum hata ile çalışabilecek bir bilişim sistemine ihtiyaç olduğu düşünülmektedir. Bilginin doğru bir şekilde yönetilebilmesi için kuşkusuz bilişim sistemlerinden yararlanmak gerekmektedir. Laudon ve Laudon’a göre (2011), bilişim sistemleri günümüz örgütleri için işlemsel mükemmeliyet, etkinleştirilmiş karar verme, yeni ürünler, hizmetler ve iş modelleri gibi üstünlükler sağlayan stratejik bir işletme fonksiyonudur. İşlemsel mükemmeliyet, süreçlerin hatasız bir şekilde yürütülmesi; etkinleştirilmiş karar verme ise doğru bilgileri kullanarak doğru kararlar verebilmek anlamına gelmektedir. Üniversitelerdeki ek ders süreçleri, işletmelerdeki finans fonksiyonunun alt bir süreci olarak düşünülebilir. Bu süreci etkili ve doğru bir şekilde yönetebilmek için, süreç içindeki bilgiyi yönetmek gerekmektedir. Doğru bilgilerle alınan doğru kararlar hem örgütsel performansı artıracak hem de stratejik bir üstünlük sağlayabilecektir.

Önerilen model ile ek ders süreçlerinin yönetilebilir bir şekle dönüştürülmesi için tasarlanan bilişim sisteminin işleyişi ve ek ders süreçlerindeki iş akışının nasıl ilerleyeceği tarif edilmektedir. Tasarlanan bilişim sistemiyle ek ders yönetim süreci yeniden belirlenecek, bütün sürecin ve hesaplamaların kanun ve yönetmelikler çerçevesinde en doğru şekilde yürütebilmesi sağlanabilecektir. Yeni süreç içinde işleyecek olan bilişim sisteminin, öğretim elemanlarının iş yükünün hafifletilmesi ve yöneticilerin karar verme ve bilgiyi yönetebilme becerilerini artırabileceği düşünülmektedir.

İş süreci, örgütsel amaçları desteklemek ve önceden belirlenmiş sonuçlara ulaşabilmek için örgütsel kaynakları kullanan, mantıksal olarak birbiriyle ilişkili bir grup görevden oluşmaktadır (Harrington, 1991, s. 9). Süreç yönetimi, sorunların çözümüne yönelik olarak mevcut süreçlerin yenilenerek örgütsel etkinliğe ulaşma çabasıdır. Süreç yönetimi, süreçleri yeniden belirleyerek maliyet, kalite, hizmet ve hız gibi çağımızın en önemli performans ölçülerinde çarpıcı gelişmelerin yapılmasını hedeflemektedir (Demirkol, 2002). Ek ders yönetim sürecinde yer alan bütün boyutların ve bu boyutlar arasındaki fonksiyonel ilişsilerin etkili bir şekilde işleyebilmesi için bir iş akış şeması oluşturulmuştur. İş akış şeması, var olan ya da önerilen yeni bir süreci semboller, çizgiler ve sözcüklerden yararlanarak süreçte yer alan faaliyetleri ve işlem adımlarını grafiksel olarak açıklama yöntemi olarak ifade edilmektedir (Harrington, 1991, s. 86). Ek ders yönetim süreçleri yeniden tasarlanarak, önerilen çözüm modeli için geliştirilecek bilişim sistemindeki iş akışı Şekil 5 'te ve iş akışındaki adımlara ilişkin açıklamalar Tablo 9'da sunulmaktadır. İş akışında görüleceği üzere süreçte yer alan boyutlar, sistem yöneticisi, öğretim elemanı, bölüm başkanı, dekan/müdür, mutemet 
ve Maliye Bakanlığı olmak üzere altı kategoriye ayrılmıştır. Her bir boyutta yer alan işlem adımları, diğer boyutlarla ilişkilendirilerek iş akışı üzerinde ayrıntılı olarak gösterilmektedir.

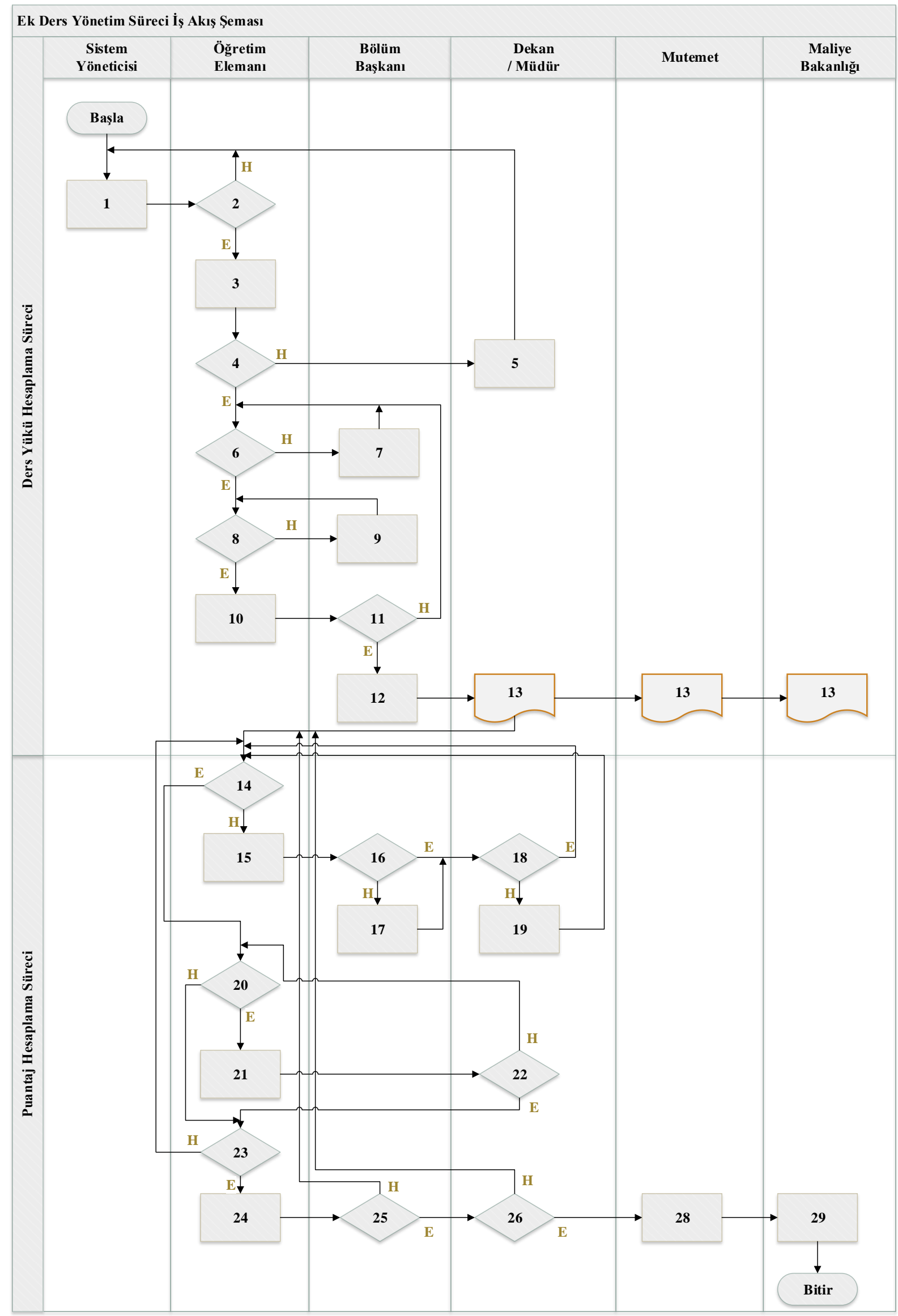




\section{Şekil 5. Önerilen çözüm modeli için geliştirilecek bilişim sistemindeki iş akışı}

Tablo 9. Bilișim sistemindeki iş akış adımlarına ilișkin açıklamalar

\section{Adım Numarası ve Açıklaması}

1. Sistem yöneticisi aktif dönemi belirler. Dönem içindeki resmi tatilleri sisteme girer. Öğrenci bilgi sisteminden birimleri, akademisyenleri, dersleri ve ders programlarını web servis üzerinden otomatik olarak çekerek sistemi hazır hale getirir.

2. Öğretim elemanının sisteme kayıtlı olup olmadığının kontrolü yapılır. Öğretim elemanının sisteme kaydı yoksa sistem yöneticisine yönlendirilip kaydının yapılması sağlanır. Varsa, 3. Adıma geçilir.

3. Öğretim elemanı sicil numarası, adı, soyadı, bağlı bulunduğu birim bilgilerini görür. İdari görevi varsa bunu kendisi düzenler, maaş karşılığını ve girmesi gereken ders yükünü sisteme işler.

4. Öğretim elemanı bilgilerinin doğruluğunu kontrol eder. Problem varsa 5. Adıma, yoksa 6. Adıma geçer.

5. Dekan/Müdür bilgileri günceller ve süreç 2. Adıma geri döndürülür.

6. Öğretim elemanı verdiği derslerin kontrolünü yapar. Problem yoksa 8. Adıma, varsa 7. Adıma geçilir.

7. Öğretim elemanının ders verdiği ilgili bölümün başkanı, öğretim elemanının derslerini günceller ve 6 . Adıma geri dönülür.

8. Öğretim elemanı ders programını kontrol eder. Problem yoksa 10. Adıma, varsa 9. Adıma geçilir.

9. Öğretim elemanının ders verdiği ilgili bölümün başkanı, öğretim elemanının ders programını günceller ve 8. Adıma dönülür.

10. Öğretim elemanı ders yükü hesaplama butonuna basarak otomatik olarak hesaplanan ders yükü tablosunu kontrol eder ve onaylar.

11. Öğretim elemanının bölüm başkanı, ders yükü tablosunu kontrol eder. Problem yoksa 12. Adıma, varsa 6. Adıma dönülür.

12. Öğretim elemanının bölüm başkanı ders yükü tablosunu onaylar.

13. Dekan/Müdür, mutemet ve Maliye Bakanlığına bağlı olarak çalışan strateji daire başkanlığı ders yükü tablolarının sistemden çıktısını alır. Dekan/Müdür tarafından imzalanan çıktılar strateji daire başkanlığında saklanır.

14. Öğretim elemanı izinli olduğu günleri, saatleri ve telafilerini kontrol eder. İzin ya da telafi yoksa 20. Adıma, varsa 15. Adıma geçilir.

15. Öğretim elemanı izinlerini (idari, rapor, saatlik vb) sisteme işler.

16. Bölüm başkanı öğretim elemanının izinlerini kontrol eder. Problem yoksa 18. Adıma, varsa 17. Adıma geçilir.

17. Öğretim elemanı almış olduğu izinleri girmemişse, bölüm başkanı öğretim elemanının izinlerini sisteme kendisi girer. Süreç 18. Adıma ilerler.

18. Dekan/Müdür öğretim elemanının izinlerini kontrol eder. Problem yoksa 14. Adıma dönülür, varsa 19. Adıma geçilir.

19. Öğretim elemanı almış olduğu izinleri girmemişse, Dekan/Müdür öğretim elemanının izinlerini sisteme kendisi girer. Süreç 14. Adıma döner.

20. Öğretim elemanı telafi kontrolü yapar. Telafi yapılacak ise 21. Adıma, yapılmayacaksa 23. Adıma geçilir.

21. Öğretim elemanı telafi yapacağı dersleri, telafi günlerini ve saatlerini sisteme girer. Sistem tarafından otomatik olarak oluşturulan telafi dilekçesi dekanlığa sunulur ve 22. Adıma geçilir.

22. Dekanlık/Müdürlük öğretim elemanı tarafından sisteme yüklenen telafi programına göre yönetim kurulu tarafından verilen karara göre telafi istediği kabul ya da ret eder. Kabul ederse 23. Adıma, etmezse ret gerekçesiyle beraber 20. Adıma dönülür.

23. Öğretim elemanı aylık puantaj hesaplaması butonuna basmadan önce son olarak izin, telafi kontrolü yapar. Problem yoksa 24. Adıma geçilir, problem varsa 14. Adıma dönülür.

24. Öğretim elemanı puantaj hesaplama butonuna basar. Puantaj hesabının yapıldığı ilgili ayda hangi birimden ne kadar ücret alacağının bilgisini ekranında görür ve onaylar.

25. Bölüm başkanı kendi birimine bağlı öğretim elemanlarının puantaj bilgilerini kontrol eder. Problem varsa ret eder ve süreç 14. Adıma döner. Problem yoksa puantajı onaylar ve 26. Adıma geçilir. 
Tablo 9. Bilişim sistemindeki iş akış adımlarına ilişsin açıklamalar

Adım Numarası ve Açıklaması

26. Dekan/Müdür kendi biriminde ders veren tüm öğretim elemanlarının puantaj bilgilerini kontrol eder. Problem varsa ret eder ve süreç 14. Adıma döner. Problem yoksa puantajı onaylar ve 27. Adıma geçilir.

27. Mutemet, dekan/müdür tarafından imzalanmak üzere onaylanan puantajların çıktısını alır. Elektronik tablo biçiminde otomatik olarak üretilen dosyayı Maliye Bakanlığının sistemine (KBS) yükler.

28. Maliye Bakanlığ 1 ek ders ödeme işlemleri için gerekli olan diğer süreçleri gerçekleştirir.

Adım 1-13’ten oluşan ders yükü hesabı, her dönem başında bir defaya mahsus olarak yapılır. Öğretim elemanının unvan bilgisinde ya da ders dağılımında bir değişiklik olursa bu adımlar tekrarlanır. Adım 14-28, ilgili ders döneminde her ay için tekrarlanır.

Önerilen çözüm modeli için geliştirilecek bilişim sisteminin, tespit edilen problemleri büyük oranda çözebileceği düşünülmektedir. Sistem işler hale geldiğinde, öğretim elemanlarınca problem olarak görülen standart kuralların bulunmaması, ücret miktarının belirsizliği, süreci karmaşık olarak görme, yanlış hesaplamalar yapma, süreç konusunda bilgi sahibi olmama gibi olgular tamamen ortadan kaldırılabilecektir. Öğretim elemanı yalnızca birkaç butona basarak ek ders yükünü hesaplayabilecek ve her ay belirlenen takvim aralığında puantaj tablosunu yine birkaç butona basarak oluşturabilecektir. Benzer şekilde bölüm başkanı birkaç butona basarak ek ders dağılımlarını, izinleri ve aylık puantajları kontrol edip onaylayabilecektir. Dekan/müdür ek ders sürecini aktif olarak kontrol edebilecek ve biriminde ders veren bütün öğretim elemanlarına ilişkin puantaj onaylama ve ödeme işlemlerini hatasız ve hızlı bir şekilde yürütebilecektir. Önerilen çözüm önerisiyle, kamu kaynaklarının etkin ve verimli bir şekilde kullanılması sağlanabilecek, zaman ve emek açısından büyük oranda tasarruf edilebilecektir.

Laudon ve Laudon'a göre (2011, s. 15), bilişim sistemi teknik olarak bir örgütte karar verme ve kontrolü destekleyecek şekilde enformasyonu toplayan, işleyen, depolayan ve dağıtan birbiriyle ilişkili bileşenlerdir. Karar vermeyi, koordinasyon ve kontrolü desteklemenin yanında, bilişim sistemleri aynı zamanda yöneticilere ve çalışanlara problemleri analiz etmede, karmaşık konuları görselleştirmede ve yeni ürünler yaratmada yardımcı olabilir. Geliştirilecek bilişim sistemiyle ek ders yönetim süreçlerinde oluşan bilgiler, sistem içinde depolanacak ve sistem içindeki birimler arasında paylaşılacaktır. Sürecin akışında bilgi anlamında yapılan herhangi bir değiş̧iklik süreçle ilgili diğer birimlerle anında paylaşılacak ve karar verme süreci hızlandırılacak ve kararların etkililik düzeyi yükseltilebilecektir.

Oluşturulacak ek ders bilişim sisteminin ders ücretlerinin etkili bir şekilde yönetilmesini sağlaması yanında farkı birtakım yararları da olabilecektir. Önerilen sistemin uygulandığı bir üniversitede karar vericiler, ders veren öğretim elemanlarını ve unvan bazlı olarak oransal dağılımlarını, ders verilen bölümleri, öğretim elemanlarının ders yüklerini, teorik ve uygulamalı derslerin oranını, herhangi bir 
dersi alan öğrencilerin sayısını, benzer derslerin kaç farklı birimde yürütüldüğünü, ders verilen günlerin oransal dağılımlarını vb. birçok bilgiyi bilişim sistemi sayesinde enformasyona dönüştürüp stratejik karar verme süreçlerinde kullanabilecektir.

\section{DEĞERLENDİRME}

$\mathrm{Bu}$ çalışmada ek ders süreçlerinde yaşanan problemler, öğretim elemanı gözüyle derinlemesine incelenmiş ve ortaya konulmuştur. Yaşanan problemlerin çözümüne yönelik bir bilişim sistemi geliştirilmesi önerisi yapılmış ve sistemin işleyişi hakkında bilgi verilmiştir. İleriki çalışmalarda farklı üniversitelerde bu çalışmada tespit edilen problemler dışında farklı problemlerin olup olmadığ incelenebilir ve tespit edilen problemler için yeni çözümler geliştirilebilir. Ayrıca, önerilen bilişim sisteminin uygulamaya konulması ile yaşanan problemlerin çözülüp çözülmediği farklı bir araştırma konusu olarak incelenebilir.

\section{KAYNAKLAR}

2547 Say1lı Kanun. (1981). Yükseköğretim Kanunu. Resmi Gazete (Tarih: 6/11/1981 Sayl: 17506). 1 Kasım, 2018 tarihinde, http://www.mevzuat.gov.tr/MevzuatMetin/1.5.2547.pdf adresinden erişilmiştir.

2914 Sayılı Kanun. (1983). Yükseköğretim Personel Kanunu. Resmi Gazete (Tarih: 13.10.1983, Sayl: 18190). 1 Kasim, 2018 tarihinde, http://www.mevzuat.gov.tr/MevzuatMetin/1.5.2914.pdf adresinden erişilmiştir.

3843 Sayılı Kanun. (1992). Yükseköğretim Kurumlarında İkili Öğretim Yapılması, 2547 Sayılı Yükseköğretim Kanununun Bazı Maddelerinin Değiştirilmesi ve Bu Kanuna Bir Ek Madde Eklenmesi Hakkında Kanun. Resmi Gazete (Tarih: 27.11.1992, Sayı: 21418). 11 Kasım, 2018 tarihinde, http://www.mevzuat.gov.tr/MevzuatMetin/1.5.2914.pdf adresinden erişilmiştir.

7100 Sayılı Kanun. (2018). Yükseköğretim Kanunu ile Bazı Kanun ve Kanun Hükmünde Kararnamelerde Değişiklik Yapılması Hakkında Kanun. Resmi Gazete (Tarih: 6 Mart 2018, Sayl: 30352). 11 Kasim, 2018 tarihinde, http://www.resmigazete.gov.tr/eskiler/2018/03/20180306-11.htm adresinden erişilmiştir.

Bakanlar Kurulu Karar1. (2013). Karar Say1s1: 2013/5556, Resmi Gazete (Tarih: 30.11.2013, Sayl: 28837). Retrieved from http://www.resmigazete.gov.tr/eskiler/2013/11/20131130-2.htm

Baş, T. ve Akturan, U. (2017). Sosyal Bilimlerde Bilgisayar Destekli Nitel Araştırma Yöntemleri (3. Bask1). Ankara: Seçkin Yayıncılık.

Büyüköztürk, Ş., Akgün, Ö. E., Karadeniz, Ş., Demirel, F. ve Kılıç Çakmak, E. (2012). Bilimsel Araştırma Yöntemleri (13. Baskı). Ankara: Pegem Akademi.

Cameron, R. (2009). A sequential mixed model research design: Design, analytical and display issues. International Journal of Multiple Research Approaches, 3(2), 140-152. doi: 10.5172/mra.3.2.140

Creswell, J. W. (2013). Nitel Araştırma Yöntemleri: Beş Yaklaşıma Göre Nitel Araştırma ve Araştırma Deseni (M. Bütün ve S. B. Demir, Çev.). Ankara: Siyasal Kitabevi. 
Creswell, J. W. ve Plano Clark, V. L. (2014). Karma Yöntem Araştırmaları Tasarımı ve Yürütülmesi (Y. Dede ve S. B. Demir, Çev. 2. Baskı). Ankara: Anı Yayıncılık.

Demirkol, Ş. (2002). Süreç Tasarım - Business Process Re-engineering (Değişim Mühendisliği). İçinde İ. Dalay, R. Coşkun ve R. Altunışık (Ed.), Stratejik Boyutuyla Modern Yönetim Yaklaşımları (ss. 163-182). İstanbul: Beta.

Ergül, H. F. (2006). Kurumlarda ücret, ücret sistemleri ve ücret - başarı ilişkisi. 5(18), 92-105.

Google. (2018). Arama cümlesi "Ders yükü tespiti ve ek ders ücreti ödemelerinde uyulacak esaslar". 22 Kasım, 2018 tarihinde, https://www.google.com.tr/search?q=Ders+yükü+tespiti+ve+ek+ders+ücreti+ödemelerinde +uyulacak+esaslar adresinden erişilmiş̧tir.

Harrington, H. J. (1991). Business Process Improvement: The Breakthrough Strategy for Total Quality, Productivity, and Competitivenes (1. Bask1). New York: McGraw-Hill.

Ivankova, N. V., Creswell, J. W. ve Stick, S. L. (2006). Using Mixed-Methods Sequential Explanatory Design: From Theory to Practice. 18(1), 3-20. doi: 10.1177/1525822x05282260

Laudon, K. C. ve Laudon, J. P. (2011). Yönetim Bilişim Sistemleri (Dijital İşletmeyi Yönetme) (U. Yozgat, Çev. 12. Baskı). Ankara: Nobel Akademik Yayıncılık.

Merriam, S. B. (2015). Nitel Araştırma: Desen ve Uygulama İçin Bir Rehber (S. Turan, Çev. 3. Baskıdan Çeviri. Baskı). Ankara: Nobel Akademik Yayıncılık.

Neuendorf, K. A. (2002). The Content Analysis Guidebook. USA: Sage Publications.

Noe, R. A., Hollenbeck, J. R., Gerhart, B. ve Wright, P. M. (2018). Fundamentals of human resource management (7. Bask1). New York, NY: McGraw-Hill Education.

Sabuncuoğlu, Z. (1991). Personel Yönetimi (6. Bask1). Bursa.

Sabuncuoğlu, Z. (2012). Insan Kaynaklarl Yönetimi (Uygulamalı) (6. Baskı Bask1). İstanbul: Beta Basım Yayım Dağıtım.

Yıldırım, A. ve Şimşek, H. (2006). Sosyal Bilimlerde Nitel Araştırma Yöntemleri (5. Baskı). Ankara: Seçkin Yayıncılık.

Yükseköğretim Kurulu. (2005a). Ders Yükü Tespiti ve Ek Ders Ücreti Ödemelerinde Uyulacak Esaslar (Genel Kurul Kararı 16 Eylül 2005). 11 Kasım, 2018 tarihinde, http://www.bumko.gov.tr/Eklenti/8598,ekdersusulesaslar.doc?0 adresinden erişilmiştir.

Yükseköğretim Kurulu. (2005b). Yükseköğretim Kurumlarında Yürütülen Tezsiz Yüksek Lisans Programları Uygulama Esas ve Usulleri (Genel Kurul Kararı 7 Nisan 2005). 11 Kasım, 2018 tarihinde, http://www.yok.gov.tr/documents/10279/3773452/Y\%C3\%BCksek\%C3\%B6\%C4\%9Fretim +Kurumlar\%C4\%B1nda+Y\%C3\%BCr\%C3\%BCt\%C3\%BClen+Tezsiz+Y\%C3\%BCksek+L isans+Programlar\%C4\%B1\%20Uygulama+Esas+ve+Usulleri.pdf/17fe54a1-af2f-4620-abea$\underline{30 \mathrm{fb} 5 \mathrm{e} 1613 \mathrm{~b} 8}$ adresinden erişilmiştir.

Yükseköğretim Kurulu. (2009). Yükseköğretim Kurumlarında Yürütülen Yaz Okulları Programları Uygulama Esas ve Usulleri (Yürürlük Tarihi 1 Ocak 2019). 11 Kasım, 2018 tarihinde, http://www.yok.gov.tr/documents/10279/3773452/Y\%C3\%BCksek\%C3\%B6\%C4\%9Fretim +Kurumlar\%C4\%B1nda+Y\%C3\%BCr\%C3\%BCt\%C3\%BClen+Yaz+Okullar\%C4\%B1\%20 Programlar\%C4\%B1\%20Uygulama+Esas+ve+Usulleri.pdf/d34b3f25-74a8-4906-82def80663ba41e8 adresinden erişilmiştir. 
Yükseköğretim Kurulu. (2015). Yükseköğretim Kurumlarında Uzaktan Öğretime İlişkin Usul ve Esaslar (Yönetim Kurulu Kararı 15 Nisan 2018). 11 Kasım, 2018 tarihinde, http://www.yok.gov.tr/documents/10279/17374/Uzaktan_ogretime_\%C4\%B0liskin_Usul_v e_Esaslar_19.06.2014+_GK_15.04.2015_YK_\%28Maliye_+Goruslu\%29.pdf/5b6dae07ff5c-4c40-8cf3-3fc7e62cac7f adresinden erişilmiştir. 